\title{
Hak Waris Anak Yang Berbeda Agama Dengan Pewaris Berdasarkan Kompilasi Hukum Islam
}

\author{
Moh Ariq Fauzan', Dewa Gde Rudy²
}

${ }^{1}$ Magister (S2) Kenotariatan Universitas Udayana, E-mail: fauzanarieq@gmail.com ${ }^{2}$ Fakultas Hukum Universitas Udayana, Email: dewarudy1959@gmail.com

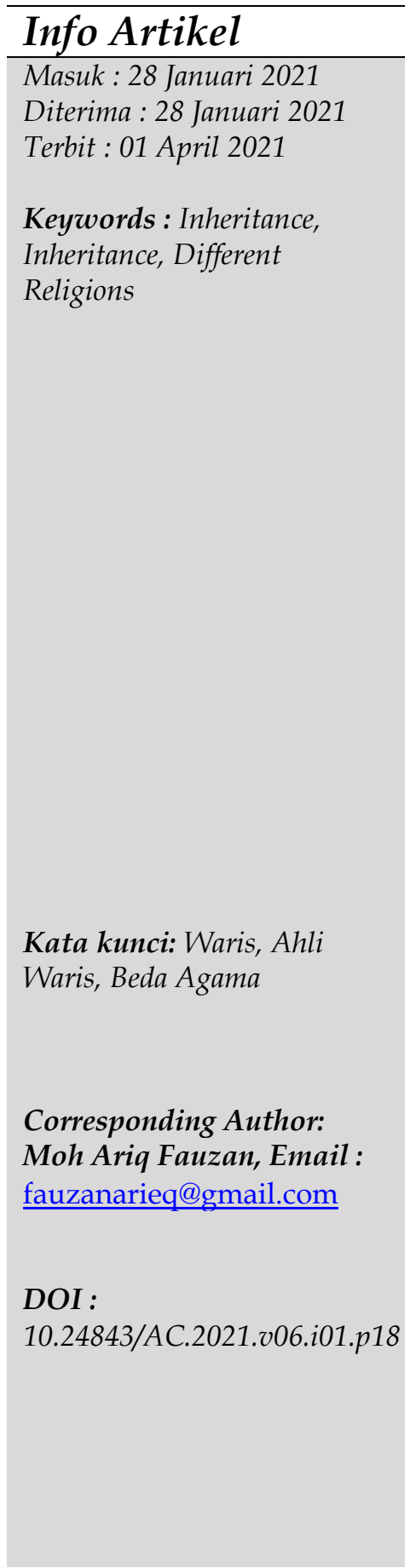

\begin{abstract}
This article purpose to find out that children of different religions have the right to inheritance from the heir and to find out how to get children of different religions to get a share of the inheritance from the heir. This paper uses a normative legal research method. The Islamic Law Compilation determines that an heir who has a different religion from his parents, in this case has a religion other than Islam, will not inherit from his parents. This means that the heirs cannot be non-Muslim. Then that an heir is obliged to be Muslim and proven by owning or based on testimony that the heir is Muslim, and if the heir is still an infant or is not yet capable, it will be considered in accordance with the religion of the parents. The resolution so that children as heirs of different religions receive inheritance from the heirs can be seen from the actions taken by judges in the form of legal breakthroughs based on the jurisprudence of the Salatiga Religious Court Decision and Determination, Badung Religious Court, and Supreme Court Judgment Jurisprudence, and in line with the views of ulama Abdul Wahab. Khallaf is based on surah al-Nisa: 11-14., Then a child or an heir who has a different religion than his parents or heirs will still receive property or inheritance that can be obtained through a will wajibaah, the inheritance obtained is not permitted more of $1 / 3$ of the inheritance.
\end{abstract}

\footnotetext{
Abstrak

Artikel ilmiah ini memiliki tujuan yaitu untuk mengetahui anak yang berbeda agama berhak atas warisan dari pewaris dan untuk mengetahui cara agar anak yang berbeda agama itu mendapatkan bagian harta warisan dari pewaris. Tulisan ini menggunakan metode penelitian hukum normatif. Kompilasi Hukum Islam menentukan bahwa seorang ahli waris yang memiliki agama yang berbeda dengan orang tuanya dalam hal ini memiliki agama selain Islam maka ia tidak akan mendapatkan warisan dari orang tuanya. Artinya ahli waris tidak boleh dari yang beragama non Islam. Kemudian seorang ahli waris diwajibkan beragama Islam dan dibuktikan dengan memiliki maupun berdasarkan kesaksian bahwa ahli waris tersebut beragama islam, dan apabila ahli waris masih bayi atau belum cakap, maka akan dipandang sesuai dengan agama orang tuanya. Penyelesaian agar anak sebagai ahli waris yang berbeda agama mendapatkan harta warisan dari pewaris dapat dilihat dari tindakan yang dilakukan hakim berupa terobosan hukum berdasarkan yurisprudensi Putusan Pengadilan Agama Salatiga dan Penetapan, Pengadilan Agama
} 
Badung, serta Yurisprudensi Putusan Mahkamah Agung, dan Sejalan dengan pandangan ulama Abdul Wahab Khallaf berdasarkan surat al-Nisa': 11-14., maka seorang anak atau seorang ahli waris yang memiliki agama berbeda dengan orang tua atau pewaris tetap memperoleh harta benda atau harta warisan yang bisa diperoleh melalui wasiat wajibaah, harta warisan yang diperoleh tidak diijinkan lebih dari $1 / 3$ dari harta waris.

\section{Pendahuluan}

Indonesia sebagai suatu bangsa dan Negara yang kaya dan beranekaragam budaya, suku, ras, agama dan bahasa yang terpisahkan antara pulau - pulau membuat Negara Indonesia menjadi Negara yang sangat beragam. "Masyarakat Indonesia adalah masyarakat yang majemuk (plural society) atau dengan kata lain Indonesia merupakan negara yang mampu mengikat secara politik dua atau lebih elemen atau unsur atau tatanan sosial untuk hidup berdampingan dan mampu membaur satu sama lain". ${ }^{1}$ Akibat pluralisme yang ada di Indonesia ini mempengaruhi beberapa bidang di Indonesia, tidak terkecuali pada bidang hukum, ini menjadi suatu yang vital mengingat Indonesia merupakan Negara hukum menurut Pasal 1 ayat (3) UndangUndang Republik Indonesia Tahun 1945 (selanjutnya disebut UUD NRI 1945).

Indonesia merupakan negara hukum, hukum yang paling dipengaruhi oleh keberagaman yang ada di Indonesia, hukum tersebut ialah Hukum Waris. "Hukum waris tersebut adalah bagian dari hukum privat yang secara harafiah mencirikan keanekaragaman hukum di Indonesia itu sendiri". ${ }^{2}$ Indonesia memiliki Hukum Waris yang terus terpengaruh dengan adanya perkembangan 3 (tiga) konsep utama dan mendasar daripada sistem pewarisan. "Ketiga sistem hukum tersebut adalah hukum adat, hukum Islam dan hukum warisan Belanda atau civil law yang banyak ditemukan dalam Burgerlijk Wetboek". ${ }^{3}$

"Pada hukum waris, masyarakat akan menemui dua masalah utama, yaitu harta warisan yang ditinggalkan oleh almarhum yang disebut sebagai warisan, dan orang yang berhak atas warisan disebut ahli waris. Apabila seseorang meninggal dunia maka hal tersebut merupakan peristiwa hukum dan yang akan menimbulkan akibat hukum yaitu bagaimana mengelola dan meneruskan suatu hak dan kewajiban seseorang yang meninggal dunia tersebut". 4 Segala pengurusan kelanjutan baik hak ataupun kewajiban orang yang sudah meninggal itu akan secara langsaung akan beralih kepada ahli waris. Ahli waris menurut Kitab Undang-Undang Hukum Perdata (selanjutnya disebut KUHPer) pada Pasal 832 ayat (1) menentukan bahwa: "Seorang

1 Dikdik Baehaqi Arif, D. B. A. (2013). Membingkai Keberagaman Indonesia: Perspektif Pendidikan Kewarganegaraan Program Kurikuler, Jurnal Universitas Ahmad Dahlan, 1 (1), h. 1

2 Ardika, I. N. (2016). Pemberian Hak Waris bagi Anak Perempuan di Bali dalam Perspektif Keadilan. Jurnal Magister Hukum Udayana, 5(4), 639-649. h. 640

${ }^{3}$ Milayani, O. (2014). Kedudukan Hukum Ahli Waris yang Mewaris dengan Cara Mengganti atau Ahli Waris "Bij Plaatsvervulling" Menurut Burgerlijk Wetboek. Al-Adl, 9(3), 405-434. h. 407

${ }^{4}$ Ibid., h. 406 
ahli waris perdata disebabkan oleh Perkawinan dan hubungan darah baik secara sah maupun tidak sah", berarti yang dapat menjadi ahli waris adalah seseorang yang memiliki hubungan darah dan/atau memiliki hubungan perkawinan.

Ahli waris yang paling mudah untuk dilakukan penelusuran adalah seorang anak hasil perkawinan antara kedua orang tuanya. Menurut UU Perkawinan pada dasarnya sebagaimana diformulasikan pada Pasal 2 bahwa perkawinan yang sah dilakukan menurut hukum masing-masing agama dan kepercayaanya. Permasalahan waris yang sering sekali muncul adalah suatu kondisi ketika orang tuanya menikah dengan memeluk satu agama tertentu, kemudian anaknya memilih untuk keluar dari agama orang tuanya, mengingat di Indonesia apabila seseorang sudah cakap umurnya secara hukum, maka anak itu dapat memeluk agama sebagaimana diatur pada Pasal 28E ayat (1) UUD NRI 1945 yang memberikan kebebasan dan pluralisme di Negara Indonesia hal ini yang mengakibatkan seorang anak dari perkawinan orang tuanya dapat memeluk agama yang berbeda dari pada orang tuanya.

Sering kali dalam hukum adat perbedaan agama dan kepercayaan mengakibatkan hilangnya hak seorang anak yang memeluk agama yang berbeda dari agama orang tuanya terhadap waris yang menjadi haknya baik itu harta maupun hutang piutang. Terutama pada hukum islam, pada Kompilasi Hukum Islam (selanjutnya disebut KHI) pada Pasal 171 huruf c menyatakan bahwa ahli waris haruslah beragama islam, sedangkan pada hukum positif Indonesia dalam hal ini KUHPer tidak terdapat pembatasan anak yang berbeda agama terhadap orang tuanya untuk mendapatkan hak nya sebagai ahli waris. Terjadi pertentangan norma antara apa yang diatur oleh KHI dan KUHPer, sehingga terdapat adanya ketidak adilan terhadap ahli waris yang memiliki agama berbeda dan akan menunjukan adanya ketidakpastian hukum yang berkaitan dengan ahli waris yang memiliki agama berbeda dengan orang tuanya.

Berdasarkan adanya pertentangan norma sebagaimana telah dipaparkan dalam latar belakang diatas menarik untuk dilakukan penelitian dengan judul "Hak Waris Anak Yang Berbeda Agama Dengan Pewaris Berdasarkan Kompilasi Hukum Islam"

Setelah dilakukan penyisiran permasalahan dapat dirumuskan suatu permasalahan yang didasarkan pada latar belakang yang telah dijabarkan, antara lain apakah anak yang berbeda agama berhak atas warisan dari pewaris? dan bagaimana caranya agar anak yang berbeda agama itu mendapatkan bagian harta warisan dari pewaris?

Artikel ilmiah ini memiliki tujuan yaitu untuk mengetahui anak yang berbeda agama berhak atas warisan dari pewaris dan untuk mengetahui cara agar anak yang berbeda agama itu mendapatkan bagian harta warisan dari pewaris.

Tulisan ilmiah ini dibuat dengan memperhatikan suatu pembaharuan hukum, agar apa yang dibuat pada tulisan ini mampu memberikan dampak untuk kepentingan ilmu hukum kedepanya, sehingga pembuatan tulisan ini adalah orisinil, artinya tidak mempunyai keinginan untuk melakukan suatu tindakan plagiat atau meniru secara utuh karya orang lain yang sudah lebih dulu ada. Adapun tulisan terdahulu yang membahas mengenai pembagian warisan oleh orang tua yang beda agama dengan anaknya yaitu : 
1) Tulisan Ilmiah yang dibuat oleh Agus Hermanto dan Habib Ismail dengan judul "Analisis Hak Waris Istri Akibat Murtad Perspektif Hukum Waris Islam dan Gender" jurnal yang terbit di At-Tahdzib: Jurnal Studi Islam Dan MuamalahVolume 8 Nomor 1 pada Bulan Agustus Tahun 2020 dengan membahasrumusan masalahnya yaitu "apakah faktor dan dampak perkawinan beda agama pada suku Bali sehingga tidak mendapatkan hak waris dan bagaimanakah hak waris akibat perkawinan beda agama perspektif hukum Islam dan gender pada masyarakat suku Bali di Desa Mulyosari Kecamatan Pasir Sakti Lampung Timur" 5

2) Tulisan Ilmiah yang dibuat oleh Abdul Mufid dengan judul "Rekonstruksi Hukum Warisan Perspektif Pluralisme Agama" jurnal ini terbit di "Al-Qadha: Jurnal Hukum Islam dan Perundang-undangan" Volume 7 Nomor 1 terbit pada Bulan Juni Tahun 2020 dengan rumusan maslah yaitu "realisasi rekonstruksi dan pertimbangan yudisial, metode dan peran hakim agama dalam penegakan, dan kontribusi ijtihad hakim agama pada penegakan hukum warisdalam pluralisme agama" 6

Berdasarkan pembanding dengan 2 (dua) tulisan ilmiah yang telah terbit terdahulu, tulisan pada tulisan ilmiah ini memiliki pembaharuan pada tulisannya. Tulisan ilmiah ini mengangkat judul "Hak Waris Anak Yang Berbeda Agama Dengan Pewaris Berdasarkan Kompilasi Hukum Islam" Pembahasan yang dibahas dalam tulisan ilmiah ini yaitu tentang apakah anak yang berbeda agama berhak atas warisan dari pewaris? dan bagaimana caranya agar anak yang berbeda agama itu mendapatkan bagian harta warisan dari pewaris?

\section{Metode Penelitian}

Penulisan tulisan ilmiah ini menggunakan jenis penelitian hukum normatif, metode hukum normatif merupakan metode penelitian yang digunakan untuk meneliti aturan hukum dengan melakukan pendekatan peraturan perundng-undangan dan mencari sumber bahan hukum pada peraturan perundang-undangan dan literatur yang ada. ${ }^{7}$ Pendekatan konsep hukum dan Pendekatan Perundang-undangan merupakan ragam jenis pendekatan penelitian hukum biasanya dipakai dan digunakan untuk membantu dalam penulisan tulisan ini.

Pendekatan Perundang-Undangan ini digunakan untuk mengkaji aturan hukum lainnya, artinya aturan hukum dikaji dengan aturan hukum terkait dan relevan mengenai permasalahan guna mencari kebenaran yang hendak dicapai. ${ }^{8}$ Pendekatan konsep hukum digunakan untuk mengkaji permasalahan guna mencari jawaban

\footnotetext{
${ }^{5}$ Hermanto, A., \& Ismail, H. (2020). Analisis Hak Waris Istri Akibat Murtad Perspektif Hukum Waris Islam Dan Gender. At-Tahdzib: Jurnal Studi Islam dan Muamalah, 8(1), 121-143.

${ }^{6}$ Mufid, A. (2020). "Rekonstruksi Hukum Warisan Di Indonesia Perspektif Pluralisme Agama ". Al-Qadha: Jurnal Hukum Islam dan Perundang-Undangan, 7(1), 60-72.

7 I Made Pasek Diantha. (2016). Metodologi Penelitian Hukum Normatif Dalam Justifikasi Teori Hukum. Prenada Media. Jakarta. h.12

8Sanjaya, I.D.M.D. (2017). Tanggungjawab Hukum Notaris Terhadap Penerbitan CovernoteDalam Pemberian Kredit. Riau Law Journal, 1(2). 180-204. h. 186
} 
dengan konsep-konsep hukum yang ada dan relevan, konsep dapat berupa doktrin para ahli hukum yang sudah lumrah digunakan oleh ahli ahli hukum lainya. ${ }^{9}$

Sumber bahan hukum pada tulisan ini menggunakan sumber hukum primer yang berupa jurnal - jurnal serta karya ilmiah di bidang hukum terkini yang relevan dengan rumusan masalah yang ada. Kemudian, bahan hukum sekunder menggunakan peraturan Perundang-undangan yang terkait tulisan ini antara lain KUHPer dan Peraturan lainya. Untuk memperoleh, mengumpulkan dan mengolah bahan hukum dalam jurnal ini dilakukan dengan teknik studi dokumen dan dianalisi dengan teknik deskripsi, suatu teknik yang menjelaskan tenta kondisi, keadaan atau prosisi-prosisi hukum.

\section{Hasil dan Pembahasan}

\subsubsection{Pengaturan Hak Waris Anak Yang Berbeda Agama Dengan Pewaris Berdasarkan Kompilasi Hukum Islam}

Membahas mengenai hukum waris, terdapat dua permasalahan utama, yaitu tentang orang yang telah tiada atau meninggal dunia sehingga menyisakan harta benda kekayaannya sebagai suatu warisan dan menyisakan orang-orang yang berhak untuk mendapatkan dan menerima harta benda peninggalan itu sendiri. Keturunan dari orang yang meninggal (pewarisan) berhak mewarisi harta peninggalan disebut "ahli waris". Menurut Pasal 830 jo. Pasal 832 KUHPer pewarisan akan terjadi karena terjadi kematian, dan pewarisan terjadi kepada orang yang berhak menjadi ahli waris, ahli waris pada prinsipnya merupakan "keluarga sedarah, baik yang sah menurut undangundang maupun yang di luar perkawinan, dan suami atau isteri yang hidup terlama dan bila keluarga sedarah dan suami atau isteri yang hidup terlama tidak ada, maka semua hartapeninggalan menjadi milik negara, yang wajib melunasi utang-utang orang yang meninggaltersebut, sejauh harga harta peninggalan mencukupi untuk itu." Artinya pada prinsipnya seorang ahli waris adalah keluarga yang memiliki hubungan darah yang sah.

Tidak semua keluarga yang terkait dengan ahli waris akan mewarisi. Posisi garis keturunan baru menawarkan kemungkinan warisan. Keluarga lebih dekat dengan ahli waris oleh karena itu, tidak termasuk kemungkinan mewarisi keluarga lain. Untuk mengetahui derajat kekerabatan keluarga, ahli waris dibagi menjadi beberapa kelompok, yaitu:

a. “Golongan pertama, keluarga dalam garis lurus ke bawah, meliputi anak-anak beserta keturunan mereka, beserta suami atau istri yang ditinggalkan atau yang hidup paling lama. Hakikat dari golongan ini ialah bahwa jika pewaris meninggalkan anak, istri atau suami dan cucu, maka cucu tidak mendapat warisan karena anak dari pewaris masih hidup.

b. Golongan kedua, keluarga dalam garis lurus keatas, meliputi orang tua dan saudara, baik laki-laki maupun perempuan, serta keturunan mereka. Dan bagi orang tua ada peraturan khusus yang menjamin bahwa bagian mereka tidak akan kurang dari $1 / 4$ bagian dari harta peninggalan, walaupun mereka mewaris

9 Wijaya, I. G. A. (2019). Kekuatan Hukum Covernote Notaris sebagai Produk Hukum Notaris. Acta Comitas: Jurnal Hukum Kenotariatan, 4(1), 90-98. h. 93 
bersama-sama saudara pewaris. Hakikat dari golongan ini ialah bahwa jika pada golongan pertama tidak terdapat ahli waris maka golongan kedualah yang berhak untuk menerima dan mewarisi harta pewaris.

c. Golongan ketiga, meliputi kakek, nenek dan leluhur selanjutnya ke atas dari pewaris. Hakikat dari golongan ini ialah jika ahli waris golongan pertama dan kedua tidak ada yang masih hidup maka ahli waris golongan ketigalah yang menjadi ahli waris.

d. Golongan keempat, meliputi anggota keluraga dalam garis kesamping dan sanak keluarga lainnya samapai drajat keenam. Hakikatnya ialah jika golongan pertama, kedua dan ketiga tidak ada maka barulah golongan keempat ini yang berperan sebagai ahli waris."10

Anak dari seorang pewaris dapat menjadi yang salah satu masuk ke dalam golongan yang pertama. Kedudukan anak dari ahli waris disini menjadi ahli waris utama dari ahli waris lainnya. Dengan cara ini, status anak dalam warisan bersifat absolut atau secara otomatis. Kemudian, sebagaimana disebutkan sebelumnya, ahli waris yang akan menerima banyak hak waris sebelumnya harus memenuhi persyaratan yaitu:

a. "Harus ada orang yang telah tiada (meninggal dunia);

b. Seorang ahli waris meninggal dunia, seorang jika ingin mewariskan warisanya, maka ahli waris harus dalam kondisi hidup. Hal yang dijelaskan tersebut tidak akan mengubah ataupun mengurangi apa yang ditentukan dalam Pasal 2 KUHPEr "Anak yang ada dalam kandungan seorang perempuan dianggap telah lahir, setiap kali kepentingan si anak menghendakinya. Bila telah mati sewaktu dilahirkan, dia dianggap tidak pernah ada." Pasal ini bermakna jika seorang anak dianggap tidak pernah ada apabila anak tersebut meninggal dunia didalam kandungan maupun saat dilahirkan. Sehingga anak di dalam kandunganpun sudah dijamin hak asasi manusianya oleh hukum, dalam hal ini dijamin haknya sebagai ahli waris hingga anak tersbeut sudah cakap hukum untuk mewaris.

c. Seorang ahli yang mewarisi sebuah warisan haruslah sudah cakap sesuai hukum serta yang terpenting berhak mewaris, artinya ia telah dinyatakan oleh ketentuan perundang-undangan sebagai seorang yang memang pantas untuk mewaris karena kematian, atau dianggap sebagai tidak cakap untuk menjadi ahli waris". ${ }^{11}$

Mengenai siapa saja yang berhak menjadi ahli waris tidak spesifik diatur begitu juga apabila seorang ahli waris yang berbeda agama dengan pewaris di KUHPer tidak ada mengatur demikian, artinya ada beberapa ketentuan dianggap tidak layak menjadi ahli waris, sehingga pengecualian dari pewaris berdasarkan pasal 838 KUHPer adalah:

a. "Mereka yang dijatuhi hukuman mati berdasarkan keputusan hakim atau yang berusaha membunuh orang mati hingga dihukum;

${ }^{10}$ Suhrawardi K. Lubis dan Komis Simanjuntak.2017. Hukum Waris Islam (Lengkap \&Praktis). Cetakan kelima. Sinar Grafika. Jakarta, h. 218

${ }^{11}$ Kadafi, M. (2019). Kedudukan Anak Yang Berbeda Agama Dengan Orang Tuanya Terhadap Harta Warisan Berdasarkan KHI Dan Hukum Perdata. Dinamika: Jurnal Ilmiah Ilmu Hukum, 25(12). h. 5 
b. Mereka yang dinyatakan bersalah oleh hakim karena mengajukan gugatan terhadap almarhum akan dihukum karena kejahatan dan dapat menghadapi hukuman 5 (lima) tahun penjara atau pernah di hukum berat;

c. Mereka yang mencegah pewaris atau almarhum untuk membuat, ingin mencabut hal hal yang akan dilakukan oleh perwaris dan mereka lakukan dengan kekerasan atau tindakan;

d. Seseorang yang menggelapkan, memalsukan atau memalsukan surat wasiat yang dibuat oleh almarhum."

Berdasarkan uraian diatas apabila seseorang anak yang berbeda agama dengan orang tua akan dilarang atau dikecualikan menjadi ahli waris ketika melakukan hal hal yang diatur oleh Pasal 838 KUHPer, artinya dalam hukum nasional atau KUHPer, walaupun ahli waris memiliki agama yang berbeda dengan pewaris tetap mendapatkan warisan dari pewaris atau orang tuanya.

Mengingat permasalahan pewarisan merupakan hal yang sangat terkait dengan agama dan kepercayaan, maka dilakukan suatu perbandingan dengan pengaturan yang dianut oleh agama islam yaitu dengan Kompilasi Hukum Islam, mengingat bagi agama islam Kompilasi Hukum Islam banyak mempengaruhi mengenai pewarisan bagi agama islam. Dalam Hukum Perdata Islam Indonesia tulisan Ahmad Rofiq disebutkan tentang ahli waris yang tidak mewarisi, yaitu tuduhan pembunuhan terhadap ahli waris sehingga tidak dapat mewarisi, Pasal 173 KHI menyatakan sebagai berikut:

"Seorang terhalang menjadi ahli waris apabila dengan putusan hakim yang telah mempunyai kekuatan hukum yang tetap, dihukum karena:

1) Dipersalahkan telah membunuh atau mencoba membunuh atau menganiaya berat pada pewaris;

2) Dipersalahkan secara memfitnah telah mengajukan pengaduan bahwa pewaris telah melakukan suatu kejahatan yang diancam dengan hukuman 5 (lima) tahun penjara atau hukuman yang lebih berat."12

Selain sebagai pembunuh KHI juga menentukan bahwa ahli waris dalam hukum islam sebagaimana diatur pada Pasal 171 huruf c yaitu "orang yang pada saat meninggal dunia mempunyai hubungan darah atau hubungan perkawinan dengan pewaris, beragama Islam dan tidak terhalang karena hukum untuk menjadi ahli waris", artinya ahli waris di ajaran islam itu harus didalam keadaan memiliki agama islam juga yang dapat jika dilakukan penafsiran hukum, ahli waris tidak boleh dari yang beragama non muslim. Kemudian hal tersebut juga dipertegas dengan diaturya juga berdasarkan Pasal 172 bahwa seorang ahli waris diwajibkan beragama islam dan dibuktikan dengan memiliki maupun berdasarkan kesaksian bahwa ahli waris tersebut beragama islam, dan apabila ahli waris masih bayi atau belum cakap, maka akan dipandang sesuai dengan agama orang tuanya.

12 Ahmad Rofiq. 2015. Hukum Perdata Islam Di Indonesia Edisi Revisi. Cetakan kedua. Rajawali Pers. Jakarta, h. 318 - 321 
Berdasarkan urian di atas menurut Kompilasi Hukum Islam memandang ahli waris yang berbeda agama sangat lah berbeda dengan KUHPer, Kompilasi Hukum Islam tidak mengakui pewarisan kepada ahli waris yang Beda agama, sedangkan KUHPer secara implisit menjelaskan bahwa seorang ahli yang akan mewarisi suatu warisan namun memiliki agama yang berbeda dengan orang tuanya itu tetap mendapatkan warisan itu sendiri, situasi yang bertentangan ini akan berdampak pada kepastian hukum mengenai pewarisan kepada ahli waris yang memiliki agama yang berbeda. Untuk menyelesaiakan permasalahan ini dapat digunakan Asas Preferensi Hukum yaitu Asas Lex Specialis Derogat Legi Generali yang pada prinsipnya menentukan bahwa peraturan yang lebih khusus mengesampingkan peraturan yang lebih umum. ${ }^{13}$ Berdasarkan asas tersebut, maka bagi penganut agama Islam yang berlaku adalah KHI, artinya seorang ahli waris yang memiliki agama yang berbeda daripada orang tuanya dalam hal ini beragama selain Islam ia tidak mungkin akan mendapatkan suatu warisan dari orang tuanya.

\subsection{Penyelesaian Agar Anak Sebagai Ahli Waris Yang Berbeda Agama Mendapatkan Harta Warisan Dari Pewaris}

KHI memandang bahwa ahli waris yang berbeda agama sangat lah berbeda dengan KUHPer. Kompilasi Hukum Islam tidak mengakui pewarisan kepada ahli waris yang beda agama, sedangkan KUHPer tidak menjadikan sebuah masalah apabila pewarisan yang ahli warisnyanya memiliki agama yang berbeda, situasi yang sangat bertentangan ini akan berdampak pada kepastian hukum mengenai pewarisan kepada ahli waris yang memiliki agama yang berbeda. Berdasarkan Asas Lex Specialis Derogat Legi Generali, aturan yang digunakan adalah KHI yang artinya seorang ahli waris yang berbeda agama dengan orangtuanya yang beragama islam tidak dapat menerima warisan dari orang tuanya tersebut, tetapi ini pada kenyataannya, penyelesaian kasuskasus warisan yang melibatkan agama Islam dan non-Islam menghadapi kendala akses keadilan (yaitu pada tahap masuk ke forum yang sesuai). Pengadilan tidak memiliki aturan atau kewenangan untuk menangani kasus warisan antar agama, yang berujung pada ketidakadilan antara ahli waris yang berbeda agama dengan orang tuanya yang beragama Islam.

Kasus menarik terjadi pada Pengadilan Agama Salatiga dan Pengadilan Agama Bandung, seorang hakim melakukan terobosan hukum terkait pembagian warisan oleh orang tua yang beda agama dengan anaknya menurut Hukum Islam. "Putusan Pengadilan Agama Salatiga No. 0413 / Pdt.G / 2011 / PA.SAL (selanjutnya disebut Putusan PA Salatiga) dan Penetapan Pengadilan Agama Badung 4 / Pdt.P / 2013 / PA.Bdg" (selanjutnya disebut Penetapan PA Bandung), keduanya sama sama terkait dengan pewarisan antara orang tua dan anak yang berbeda agama namun terdapat perbedaan konsekuensi hukum dari kedua putusan dan penetapan tersebut bagi ahli warisnya yang memiliki agama yang berbeda dengan pewaris, perbedaannya yaitu, menurut putusan Pengadilan Agama Salatiga, "ahli waris yang berbeda agama disebut juga sebagai ahli waris", dan menurut putusan Pengadilan Agama Badung, "apabila pewaris dan ahli waris memiliki perbedaan dalam agama ahli waris tersebut tidak dapat menjadi ahli waris atau memperoleh warisan, namun dapat diberikan warisan

13 Sucipta, P. R., Syahputra, I., \& Sahindra, R. (2020). Lex Specialis Derogat Legi Generali Sebagai Asas Preferensi Dalam Kecelakaan Angkutan Laut Pelayaran Rakyat. Jurnal IUS Kajian Hukum dan Keadilan, 8(1), 140-150. h. 143 
melalui wasiat wajibah dan bersedia memperoleh hak waris". Berdasarkan putusan Mahkamah Agung RI No. 51/K/AG/1999 dan No. 16/K/AG/2010 (keduanya selanjutnya disebut Putusan Mahkamah Agung), "seorang yang adalah ahli waris walaupun berbeda agamanya dengan pewaris tetap mendapatkan warisan melalui wasiat wajibaah dan memperoleh harta warisan serta bagian dari yang akan mewarisi sama dengan ahli waris yang derajatnya sama namun bagiannya tidak lebih dari sepertiga harta warisan". ${ }^{14}$ "Pada putusan tersebut tergambarkan bahwa hakim tidak saja menegakan hukum semata, namun hakim melakukan kewajibanya untuk menggali, mengikuti, dan memahami nilai dan rasa keadilan yang terjadi di masyarakat sebagaimana amanat Pasal 5 ayat (1) UU Kehakiman".$^{15}$

Secara garis besar wasiat merupakan pemberian yang akan diberikan kepada seseorang atau beberapa orang yang bukan ahli waris setelah seseorang meninggal. Kehendak adalah tasharruf (masalah) yang diwarisi setelah kematian. Menurut hukum, "wasiat ladalah perbuatan yang dilakukan sesuai dengan keinginan batin dalam keadaan bagaimanapun. Karena tidakdiatur dalam syariat atau hukum Islam, maka harus ditegakkan melalui putusan hakim". ${ }^{16}$ Guna memperjelas tentang kehendak maka perlu dilakukan pembahasan tentang pengertian surat wasiat berdasarkan hukum perdata, karena Pasal 875 KUHP mengatur tentang kehendak hukum perdata, yaitu: "Surat wasiat atau testamen adalah suatu akta yang memuat prnyataan seseorang tentang apa yang dikehendakinya akan terjadi setelah ia meninggal dunia, dan yang olehnya dapat dicabut kembali"

Antara Hukum perdata dan hukum Islam memiliki kesamaan saat akan membahas mengenai wasiat, kedua hukum ini membahas keberlakuan suatu kehendak itu adalah setelah seorang yang membuat wasiat meninggal dunia. Seseorang sangatlah bebas untuk membuat atau tidak sebuah surat wasiat namun, untuk anak dari pewaris yang beda agama dengan pewaris sebaiknya membuat wasiat agar ketika nantinya pewaris meninngal dunia anak yang berbeda agama tersebut tetap menerima harta warisan dari pewaris.

Penyelesaian terhadap pembagian warisan oleh orang tua yang memiliki anak yang beda agama menurut hukum islam berdasarkan yurisprudensi Putusan Pengadilan Agama Salatiga, Penetapan Pengadilan Agama Badung, serta Yurisprudensi Putusan Mahkamah Agung membuat wasiat wajibah adalah cara agar ahli waris beda agama tetapmemperoleh harta waris dengan perhitungan adalah tidak boleh lebih dari 1/3 harta yang akan diwarisi atau memperoleh sama dengan ahli warisyang sederajat.

Mengenai hal tersebut di atas, sejalan dengan pandangan para ulama. Seriap orang pada dasarnya mempunyai hak untuk mewarisi harta benda yang dimiliki atau diinginkan, namun perlu mematuhi undang-undang yang mengatur tentang harta tersebut. Terdapat ketentuan dalam peraturan Perundang-undangan agar pelaksanaannya tidak merugikan pihak lain. Mengenai Undang-Undang berikut ini,

14 Yanti, S. S. Y., \& Mulyadi, Y. (2016). Pembagian Harta Warisan Terhadap Ahli Waris Beda Agama Serta Akibat Hukumnya. Diponegoro Law Journal, 5(3), 1-12. h. 9

${ }^{15}$ Suhariyanto, B. (2015). Eksistensi pembentukan hukum oleh hakim dalam dinamika politik legislasi di Indonesia. Jurnal Rechts Vinding: Media Pembinaan Hukum Nasional, 4(3), 413-430. h. 414

${ }^{16}$ Hasbi Ash-shiddieqy, 2001,fiqh Muwaris, Pustaka Rezki Putra, Jakarta, h. 273 
secara hukum diperbolehkan (ahli waris) untuk mewarisi sebagian dari harta yang diinginkan oleh ahli waris (li al-nadb), selama tidak melebihi ahli warisnya tidak ada perbedaan pendapat dari "Abu Hanifah, Malik, Syafi'i dan Ahmad bin Hanbal" tidak melebihi sepertiga dari hartanya. Dasar-dasar: Pertama, Hadits "la washiyyah liwaritsin", yaitu: "Sesungguhnya Allah telah memberikan setiap yang mempunyai hak akan haknya, maka tidak ada wasiat bagi ahli waris". Kedua, hadis "la washiyyah liwaritsin illa an yasya'a al-waratsah" yaitu: "Bahwa tidak boleh berwasiat untuk ahli waris, kecuali jika dikehendaki oleh ahli waris (yang lainnya)" dan Ketiga, mengenai Hadis dalam hal yang dilakukan Sa'ad bin Abi Waqas, ia berniat menyumbangkan 2/3 dari hartanya, sehingga jawaban nabi terakhir paling banyak tiga pertiga. Satu, ini sudah banyak. ${ }^{17}$ "Abdul Wahab Khallaf berkeyakinan bahwa jika seorang anak yang beragama muslim memiliki harta yang banyak, maka anak tersebut sebagai seorang muslim wajib mewarisi hartanya yaitu sebagian diperuntukan untuk bapak dan ibunya atau saudaranya yang tidak beragama muslim", Hal yang dilakukan berpandangan yang didasari oleh Surat al-Baqarah: 180 "perintah yang harus diikuti oleh ahli waris umat Islam biasa. Tapi perintah ayat ini sudah dinasakh dengan turunnya surat al-Nisa': 11-14. Masih berlaku adalah keinginan khusus kerabat yang tidak dapat memperoleh hak waris karena perbedaan agama". ${ }^{18}$

\section{Kesimpulan}

Berdasarkan hasil dari pembahasan yang sudah dijabarkan di atas, sehingga dapat ditarik kesimpulan sebagai berikut:

1. Kompilasi Hukum Islam menentukan bahwa seorang ahli waris yang memiliki agama yang berbeda dengan orang tuanya dalam hal ini memiliki agama selain Islam maka ia tidak akan mendapatkan warisan dari orang tuanya. Artinya ahli waris tidak boleh dari yang beragama non Islam. Kemudian hal tersebut juga dipertegas dengan diatur juga berdasarkan Pasal 172 bahwa seorang ahli waris diwajibkan beragama Islam dan dibuktikan dengan memiliki maupun berdasarkan kesaksian bahwa ahli waris tersebut beragama islam, dan apabila ahli waris masih bayi atau belum cakap, maka akan dipandang sesuai dengan agama orang tuanya.

2. Penyelesaian agar anak sebagai ahli waris yang berbeda agama mendapatkan harta warisan dari pewaris dapat dilihat dari tindakan yang dilakukan hakim berupa terobosan hukum berdasarkan yurisprudensi Putusan Pengadilan Agama Salatiga dan Penetapan, Pengadilan Agama Badung, serta Yurisprudensi Putusan Mahkamah Agung, dan Sejalan dengan pandangan ulama Abdul Wahab Khallaf berdasarkan surat al-Nisa': 11-14., maka seorang anak atau seorang ahli waris yang memiliki agama berbeda dengan orang tua atau pewaris tetap memperoleh harta benda atau harta warisan yang bisa diperoleh melalui wasiat wajibaah, harta warisan yang diperoleh tidak diijinkan lebih dari $1 / 3$ dari harta waris atau hanya sebanyak harta warisan dari ahli waris yang sederajat.

${ }_{17}$ Maimun, M. (2017). Pembagian Hak Waris Terhadap Ahli Waris Beda Agama Melalui Wasiat Wajibah Dalam Perspektif Hukum Kewarisan Islam. ASAS, 9(1).1-14. h. 8-9

${ }^{18}$ Ibid. h. 9 


\section{Daftar Pustaka}

\section{Buku}

Rofiq, A. (2015). Hukum Perdata Islam Di Indonesia Edisi Revisi, Cet 2. Jakarta: Rajawali Pers.

Ash-Shiddieqy, T. M. H. (2001). Fiqh Mawaris. Cet. I., Jakarta : Pustaka Rezki Putra.

Diantha, I. M. P., \& SH, M. (2016). Metodologi penelitian hukum normatif dalam justifikasi teori hukum. Jakarta : Prenada Media.

Lubis, S. K., \& Simanjuntak, K. (2017). Hukum Waris Islam (lengkap \& praktis), Jakarta : Sinar Grafika.

\section{Jurnal Ilmiah}

Ardika, I. N. (2016). "Pemberian Hak Waris bagi Anak Perempuan di Bali dalam Perspektif Keadilan". Jurnal Magister Hukum Udayana, 5(4), 639-649

Dikdik Baehaqi Arif, D. B. A. (2013). Membingkai Keberagaman Indonesia: Perspektif Pendidikan Kewarganegaraan Program Kurikuler, Jurnal Universitas Ahmad Dahlan, 1 (1)

Hermanto, A., \& Ismail, H. (2020). Analisis Hak Waris Istri Akibat Murtad Perspektif Hukum Waris Islam Dan Gender. At-Tahdzib: Jurnal Studi Islam dan Muamalah, 8(1), 121-143.

Kadafi, M. (2019). “Kedudukan Anak Yang Berbeda Agama Dengan Orang Tuanya Terhadap Harta Warisan Berdasarkan KHI Dan Hukum Perdata". Dinamika: Jurnal Ilmiah Ilmu Hukum, 25(12).

Maimun, M. (2017). Pembagian Hak Waris Terhadap Ahli Waris Beda Agama Melalui Wasiat Wajibah Dalam Perspektif Hukum Kewarisan Islam. ASAS, 9(1).1-14

Milayani, O. (2014). Kedudukan Hukum Ahli Waris yang Mewaris dengan Cara Mengganti atau Ahli Waris "Bij Plaatsvervulling" Menurut Burgerlijk Wetboek. Al-Adl, 9(3), 405-434.

Mufid, A. (2020). Rekonstruksi Hukum Warisan Di Indonesia Perspektif Pluralisme Agama. Al-Qadha: Jurnal Hukum Islam dan Perundang-Undangan, 7(1), 60-72.

Sanjaya, I.D.M.D. (2017). Tanggungjawab Hukum Notaris Terhadap Penerbitan CovernoteDalam Pemberian Kredit. Riau Law Journal, 1(2). 180-204.

Sucipta, P. R., Syahputra, I., \& Sahindra, R. (2020). Lex Specialis Derogat Legi Generali Sebagai Asas Preferensi Dalam Kecelakaan Angkutan Laut Pelayaran Rakyat. Jurnal IUS Kajian Hukum dan Keadilan, 8(1), 140-150. 
Suhariyanto, B. (2015). Eksistensi pembentukan hukum oleh hakim dalam dinamika politik legislasi di Indonesia. Jurnal Rechts Vinding: Media Pembinaan Hukum Nasional, 4(3), 413-430.

Wijaya, I. G. A. (2019). Kekuatan Hukum Covernote Notaris sebagai Produk Hukum Notaris. Acta Comitas: Jurnal Hukum Kenotariatan, 4(1), 90-98.

Yanti, S. S. Y., \& Mulyadi, Y. (2016). Pembagian Harta Warisan Terhadap Ahli Waris Beda Agama Serta Akibat Hukumnya. Diponegoro Law Journal, 5(3), 1-12.

\section{Peraturan Perundang - Undangan}

Kitab Undang - Undang Hukum Perdata

Kompilasi Hukum Islam 